\title{
O PODER PUNITIVO ESTATAL X OS DIREITOS FUNDAMENTAIS DO ACUSADO: ESTABELECENDO AS REGRAS PARA UMA RACIONALIDADE PENAL
}

\author{
Alexandra Fonseca Rodrigues \\ Alexandre Manuel Lopes Rodrigues
}

\section{RESUMO}

Este trabalho possui como objetivo principal efetivar uma análise do Poder Punitivo Estatal e dos direitos fundamentais do acusado sob a luz das regras que deveriam ser utilizadas quando da adoção de uma racionalidade penal crítica e valorativa. O escopo, será, então, entender quais os limites para que o exercício do jus puniendi estatal não venha a sacrificar os direitos e garantias do réu, reservando a este um papel de inimigo estatal que deve ser punido a qualquer custo. Para tanto, será proposto o estudo das relações de Poder Estatal, especialmente no âmbito criminal; dos direitos fundamentais que devem ser atribuídos ao acusado para que este não se torne apenas alvo de repressão criminal; e das regras que devem ser obedecidas para a construção de um Direito material e processual Penal mais efetivo, racional, crítico e constitucionalizado.

PALAVRAS-CHAVE: Poder Punitivo Estatal. Direitos fundamentais do acusado. Racionalidade Penal. Direito penal. Processo Penal.

\section{THE STATE PUNITIVE POWER X THE FUNDAMENTAL RIGHTS OF THE ACCUSED: SETTING THE RULES FOR A CRIMINAL RATIONALITY}

\begin{abstract}
This work has as main objective to carry out an analysis of the State Punitive Power and the fundamental rights of the accused under the light of the rules that should be used when adopting a critical and evaluative criminal rationality. The scope, then, will be to understand the limits so that the exercise of the jus puniendi state will not sacrifice the rights and guarantees of the defendant, reserving to him a role of state enemy that must be punished at any cost. To do so, it will be proposed the study of State Power relations, especially in the criminal sphere; of the fundamental rights that must be assigned to the accused so that he is not only the target of criminal repression; and the rules that must be obeyed for the construction of a more effective, rational, critical and constitutionalized material and procedural Law.
\end{abstract}

KEY WORDS: State Punitive Power. Fundamental rights of the accused. Criminal Rationality. Criminal law. Criminal proceedings.

\section{INTRODUÇÃO}

O presente estudo irá analisar o Poder Punitivo Estatal e os direitos fundamentais do acusado sob a luz de uma racionalidade penal crítica; objetivando entender até que ponto e, de que forma, o jus puniendi estatal pode ser exercido para que não ponha em risco, ou mesmo 
em sacrifício, as garantias fundamentais do réu. Prega-se, então, a busca por um Direito material e processual Penal constitucionalizado, que tenha a defesa e proteção dos direitos humanos como valor máximo e que não sinalize o acusado criminal como inimigo estatal.

Para tanto, primeiramente, há de se entender a estrutura do Estado Moderno e suas ideias de governo, nos moldes da melhor doutrina explicativa da Teoria Geral estatal; para que, posteriormente, com o auxílio de Michel Foucault, compreenda-se a relação de Poder estatal exercida sobre os indivíduos na forma de controle e produção de saber; e, finalmente, se raciocine como o exercício de tal Poder pode levar à construção de violência legitimada e à consequente crise dos mecanismos de Direito Penal.

De posse de tais informações fundamentais para forjar uma base inicial sobre o tema, num segundo momento, faz-se mister explicar a importância do Direito Criminal para a concretização dos direitos fundamentais. Ressaltando-se a necessidade de tal instrumento para a garantia dos mencionados direitos não apenas num plano formal, mas também material; bem como para desconstituir a visão do acusado como alvo da inimizade estatal e atribuir a este o devido caráter de sujeito de direitos, do qual é merecedor.

Finalmente, será possível forjar entendimento acerca das regras do jogo penal, enfocando seu real objeto processual; e sobre a necessidade de se alcançar o equilíbrio entre poder acusatório, direito de defesa e poder punitivo, bem como sobre a importância de constitucionalização do âmbito criminal. Para que, cabalmente, se conclua pela necessidade de utilização das regras criminais de forma racional e crítica, adequando-se a contexto social concreto; mas sem se deixar sucumbir a falta de alinhamento com os preceitos e direitos de cunho fundamental.

\section{ESTADO, GOVERNO E PODER}

A análise do ente estatal requer o estudo de um sem número de teorias que tentaram justificar sua origem e seus propósitos. Muitas delas possuem seus méritos, seja num viés mais sociológico, psicanalítico, ou no campo das Ciências Políticas. Contudo, levando em conta o contexto atual do Estado democrático de Direito brasileiro e os objetivos deste trabalho, a teoria contratualista veste melhor as tentativas de elucidação acerca do Estado e das relações de Poder que dele derivam. Em meio às relativas variações que cada ramificação da Teoria Contratualista pode adotar; aqui se utilizará o raciocínio de John Locke; 
posto que este apresenta ideário mais compatível com as atuais aspirações do Estado de Direito e das doutrinas que pregam e defendem os direitos fundamentais.

Locke (1998) afirmava que, no Estado de Natureza todos os homens já seriam dotados de certos direitos inerentes à sua própria natureza humana e que, portanto, seriam universais. A passagem para o Estado Civil, realizada através do advento do contrato social, apenas faria com que o Estado assumisse oficialmente o compromisso de proteger e garantir a efetivação de tais direitos. O dever principal do Estado seria, então, o de fazer valer os direitos fundamentais dos indivíduos governados; ao mesmo tempo em que tais direitos seriam as balizas para a referida atuação estatal. Destarte, fala em dois tratados que são firmados entre povo e governo soberano: um com natureza de associação e pelo qual se fundam as estruturas da sociedade civil; e outro pautado em uma relação se submissão, que institui o Poder Político. Portanto, ao firmar o Contrato Social, os indivíduos não cedem para o Estado nenhum de seus Direitos; pelo contrário, obrigam tal ente a cumpri-los e respeitá-los. A única liberdade da qual os indivíduos se desfazem ao reconhecer a soberania estatal é a de fazer justiça com as próprias mãos (STRECK, MORAIS, 2014).

Desde o nascimento do Estado Moderno, portanto, o Poder se torna uma instituição, ou seja, a autoridade passa a ser vista como dissociada da pessoa que a exerce; autônoma. E, já que tal Poder é despersonalizado, precisa de quem o titularize e, quem o fará, será o Estado (STRECK, MORAIS, 2014).. Sendo assim, faz-se mister entender como se desenvolvem as relações de poder e, posteriormente, adicionar a tal contexto a ideia de soberania estatal e os paradigmas de Direito, sobretudo o Penal.

\subsection{Direito, Violência e Crise do Controle Estatal}

Constitui senso comum a afirmação de que o Direito surgiu como meio de resolução alternativa de conflitos à vingança privada que, durante muito tempo foi a regra entre as sociedades primitivas. No período da vingança privada imperava a Lei de Talião, assim, qualquer indivíduo que sofresse um dano ou ofensa por parte de outrem, deveria resolvê-lo por sua própria conta e através dos meios que mais julgasse adequado. Neste contexto, portanto, o Direito veio propor uma solução jurídica para a resolução de conflitos, aonde um terceiro imparcial seria o responsável por analisar a situação e aplicar a decisão mais justa. Utilizar-se das vias jurídicas seria equivalente ao abandono da violência e da pura vingança. 
Ocorre que, na realidade, como afirma Oswaldo Giacoia Junior (2018), a partir do momento em que as partes optam por ceder à resolução judicial, ainda que de maneira pacífica; em algum momento haverá violência atual ou virtual. Pois, o contrato de Direito confere às partes o direito de recorrer a violência contra a outra, caso esta rompa ou não cumpra com o pactuado. Como afirma Sérgio Adorno (2002, p.09): “A violência não é o posto do Poder, porém um de seus fundamentos, que inclusive conferem ao Estado sua capacidade de garantir as liberdades públicas e civis”. Tal presença inevitável da violência se dá, sobretudo, pelo fato de que o Poder que garante a existência e a efetividade do Direito é de origem violenta. Como o Direito considera caótico e perigoso o exercício da violência pelos indivíduos, toma para si o monopólio estatal da força e da violência instituída através da lei.

Assim, o Estado é quem detêm o monopólio da soberania jurídico-política e também da violência física admitida por lei (adorno,2002). O Estado se vale, então, de dois tipos de violência para garantir seu controle sobre os indivíduos, que Giacoia (2018) classifica da seguinte forma: uma violência originária, aplicada quando da instauração da ordem jurídica e possível de ser representada pelo Poder Constituinte; e uma segunda violência utilizada para assegurar a aplicação das leis e normas e efetuada pelos mais diversos órgãos, agentes e aparelhos estatais. Aqui, então, aparece o Direito como duplo instrumento de realização deste poderio estatal, pois, ao mesmo tempo em que irá definir os limites para a intervenção pública, também irá arbitrar com imparcialidade os conflitos que possam vir a surgir na vida privada (ADORNO,2002).

Ocorre que, atualmente, os Estado democráticos tem passado por um momento de grave crise funcional (STRECK,MORAIS, 2014), no qual o perfil tradicional de Estado tem sido alterado, seja pela própria evolução natural do ente, ou seja pela fragilização que esta figura sofre quando se deixa ser superada pela concorrência privada, pelos mercados internacionais e mesmo pela criminalidade. Além disso, como esclarece De Giorgi (2018), com o surgimento das novas gerações de direitos fundamentais - coletivos e transindividuais, por exemplo - o sistema de Direito gerenciado pelo Estado tem se tornado cada vez mais especificado, tornando maior e mais rígida a necessidade de legalidade. Daí decorre que, ao mesmo tempo em que um número grande de direitos encontra acolhimento constitucional; cresce a legitimação da violência estatal e a produção de desigualdades através do próprio exercício do Direito. 
Diante destes fatores, o Estado tem perdido capacidade de regulação e, consequentemente, força soberana; tornando-se mais ativista e violento para tentar recuperar o espaço que, supostamente, foi perdido. Nas palavras de De Giorgi (2018, p.74): “É assim que a era dos direitos se manifesta como era da exclusão, da marginalização, do isolamento imunizante". Portanto, o reconhecimento das diferenças e a produção de mais direitos acarreta, ao mesmo tempo, seletividade e mais discriminação; o que, por sua vez, gera mais exclusão e faz aumentar o aparecimento de sistemas paralelos ao estatal; enfraquecendo a força deste último. Diante deste quadro e, como uma tentativa de reação, muitas vezes o Estado pode vir a praticar atos de violência que extrapolam os limites legais, tornando-se, portanto, ilegítima (ADORNO, 2002).

Trazendo tal problemática para o âmbito criminal, tem-se que a perda de controle estatal sob a criminalidade, a violência e a vingança privada têm trazido, como efeito colateral, doutrinas e teses jurisprudenciais que pregam cada vez mais um Direito Penal do ódio, onde o réu deve ser visto como inimigo do Estado, a ser combatido a qualquer custo; mesmo ao custo do sacrifício de direitos fundamentais e da dignidade da pessoa humana. A vida do réu, que deveria ser tutelada como bem supremo, assim como as demais; perde valor e deve ser sacrificada, se preciso for, para recompor a moral estatal e mostrar à sociedade que o domínio ainda está nas mãos do forte e temido leviatã hobbesiano ${ }^{1}$.

Desde o Estado moderno, com o advento da noção de monopólio estatal sobre o Poder; pode-se afirmar que o Direito Penal que é aplicado pelo Estado - e até mesmo pela sociedade, quando esta se vê obrigada a assumir as funções estatais -, se representa como um tipo de Poder vigilante e controlador que Foucault (2002) denomina de "Poder disciplinar". Disciplinando os indivíduos o Poder Criminal confere se estes estão ou não agindo conforme as regras e preocupa-se em desvendar se algum ato ilegal foi praticado e por quem - o que corresponde perfeitamente aos sagrados conceitos de materialidade e autoria que fundamentam o Direito Criminal contemporâneo. O poder penal é exercido, então, sob a forma de um panóptico, onde vigilância, controle e correção são as bases do sistema (FOUCAULT, 2002).

Entretanto, o crescimento desenfreado da violência urbana nas últimas décadas tem feito despontar, a cada dia mais, na sociedade, os sentimentos de medo, insegurança e

\footnotetext{
${ }^{1} \mathrm{Na}$ obra constratualista de Thomas Hobbes: O Leviatã; o Estado era representado como um grande monstro marinho chamado de Leviatã; por isso era temido e respeitado por todos os indivíduos.
} 
impotência diante dos riscos. Tal contexto resulta em cobranças e apelos da opinião pública e em pressão midiática por segurança a qualquer custo; o que tem produzido sensíveis mudanças no sistema criminal, que precisa dar conta de propor e efetivar políticas públicas penais. Assim, movendo-se num sentido contrário ao das doutrinas clássicas que buscavam uma restrição do Direito Penal, atualmente as camadas populares e mesmo boa parte da comunidade acadêmica, clamam pela ampliação e intensificação do Poder Penal Estatal.

Some-se a isso o fato de que o crime tem se tornado cada vez mais organizado, sofisticado e complexo; de modo que as agências estatais responsáveis por fazer cumprir a lei penal e garantir a segurança pública, muitas vezes por falta de recursos, investimento e atualização, tornam-se ultrapassadas e inócuas diante da ação delitiva. Destarte, a própria comunidade se torna co-responsabilizada pelo provimento da segurança pública e do combate à criminalidade; o que ressalta ainda mais a perda do monopólio estatal da legítima violência (ADORNO,2002). Perdendo o monopólio, o Estado abre as portas para as grandes milícias, carteis e demais organizações criminosas que, se voltam contra este ente e servem à população; a qual, por sua vez, fica descrente do Poder Público e passa a buscar auxílio neste poder criminal paralelo.

Paralelamente ao enfraquecimento do poderio estatal com relação à violência e à descrença da população na segurança que tal organismo pode propiciar; vem, ainda, uma aversão à efetivação dos direitos humanos de qualquer indivíduo que esteja relacionado de algum modo com a criminalidade. Diante do temor, da insegurança e da vitimização, tudo o que importa para a sociedade é a segurança; muito mais do que o respeito a direitos e garantias do acusado e a obediência a normas e princípios penais, que passam a ser encarados pela população como formalismos excessivos e desnecessários (BECHARA,2008).

\section{O PENAL COMO CONCRETIZADOR E GARANTIDOR DE DIREITOS FUNDAMENTAIS}

No contexto de um Estado Constitucional de Direito, a Constituição Federal há de representar não apenas os limites para as intervenções estatais, como almejado no liberalismo; e nem somente a imposição das prestações estatais positivas reconhecidas com o Estado Social, mas também e, sobretudo, como o centro axiológico norteador de todo o ordenamento infraconstitucional e, exigindo a eficácia direta dos direitos fundamentais em todas as áreas do saber e da prática jurídica. 
Luiz Edson Fachin (2000), em suas obras dedicadas ao estudo do Direito Civil, afirma que o reconhecimento da força normativa da Constituição seria capaz de operar uma "virada de Copérnico" no Direito Privado, no sentido de que, o mundo jurídico se daria conta de que o centro do ordenamento civil não é o código ou as leis ordinárias que tratam sobre o tema, mas sim a Carta Constitucional. Tal colocação também pode, por seus próprios fundamentos, ser aplicada ao Direito Penal, que tem sofrido com uma avalanche de leis extravagantes editadas sob o pretexto de fomentar a segurança jurídica, mas que, na realidade, são vazias de eficácia. A ideia é que todos os ramos do direito sejam preenchidos com os valores constitucionais de liberdade, igualdade e solidariedade; os quais, por sua vez, ensejarão uma releitura dos conceitos e institutos tradicionais de cada saber jurídico que, passarão a ser interpretados e aplicados dentro da axiologia do Texto Maior.

Trabalhando ao lado dos direitos fundamentais, as garantias são as técnicas concebidas pelo ordenamento para reduzir o abismo entre o dever-ser normativo e a efetividade do que realmente é, possibilitando a máxima eficácia dos direitos fundamentais em todas as searas jurídicas (FERRAJOLI, 2011). Ocorre que, a relação dos direitos subjetivos com as garantias que os correspondem se dá de maneira diversa entre os direitos patrimoniais e os de caráter fundamental. A relação entre direitos de patrimônio e as normas que os garantem é quase que simultânea, pois, v.g, o débito de um vem junto com o crédito de outro. Entretanto, na seara fundamental, em razão das características peculiares dos direitos, como a universalidade; é muito difícil embutir no teor dos próprios direitos as garantias que lhe fazem jus. Portanto, na maioria das vezes, para serem garantidos, os direitos fundamentais requerem a edição de normas específicas que servirão de instrumento para sua efetivação (Ferrajoli, 2011b).

Sendo assim tem-se que o processo, enquanto conjunto de atos jurídicos concatenados e destinados à obtenção de um provimento jurisdicional, seja ele de qualquer espécie, constitui, por si só, uma garantia fundamental atribuída aos cidadãos pela Carta Magna. Fica latente, portanto, que o Processo Penal é o instrumento apto para que o Direito Penal seja concretizado dentro dos parâmetros axiológicos propostos pela Carta Constitucional e com observância aos direitos fundamentais. Nos moldes apontados pelo constitucionalismo garantista, estão lançadas as bases para o desenvolvimento de um devido processo legal penal, capaz se assegurar às partes e, principalmente ao réu, o desenvolvimento de um procedimento penal correspondente ao maior grau possível de tutela das garantias e direitos, diminuindo 
consideravelmente a possibilidade do cometimento de injustiças e o sofrimento causado pelo processo judicial, pois o simples desenrolar deste já é uma pena em si mesmo (GLOECKNER,2009).

A Carta Magna de 1988, portanto, tem o grande mérito de ter positivado no Brasil o devido processo legal substantivo, mais amplo e garantidor do que o devido processo meramente adjetivo que, até então, vinha sendo paulatinamente adotado pelo ordenamento jurídico nacional (MATTOS,2009). O devido processo adjetivo restringe-se ao campo formal - e corresponde a um constitucionalismo meramente formal- delimitando o aspecto procedimental e externo do processo para que seja considerado legal; já o devido processo substantivo representa a evolução deste último - num contexto de democracia substancial- ao abarcar o aspecto material que pugna por um processo justo, dotado de lógica valorativa e destinado aos três poderes estatais, para garantir a melhor elaboração, interpretação e execução das normas (GIACOMOLLI, 2011).

Ressalta-se, entretanto que, para a efetivação dos direitos fundamentais, especialmente do ponto de vista criminal, não é suficiente apenas a existência do processo e o exercício da jurisdição pública, com o escopo de se afastar a vingança privada e a consequente retribuição do mal com o mal. Mas, para que tal instrumento de resolução de conflitos tenha concretude, é necessário enxertá-lo com diversas garantias que tornem a solução de conflitos judiciais menos arbitrária, já que tal impasse é decidido por um ente estatal estranho à relação das partes e aos deslindes do fato. Para que o Processo Penal seja considerado devido e legal, é necessário, portanto, que dele decorra a garantia da paridade de armas entre acusação e defesa, de modo que autor e réu possuam as mesmas oportunidades de argumentação e produção de provas.

\subsection{A importância dos direitos fundamentais do acusado para pôr fỉm à visão autoritária de inimigo estatal}

Em face do exposto, percebe-se, então, a vinculação indelével entre devido processo e o garantimento de direitos ao acusado, que o assegurem ao menos uma condenação pautada em preceitos legais e não levada a cabo arbitrariamente pelo Poder Punitivo estatal. Tal conferência de direitos processuais ao acusado dependerá, portanto, do tipo de sistema criminal adotado; pois em sistemas de viés inquisitório e ditatorial, o réu tende a ser tratado como mero objeto do processo; sendo ideal, então, a adoção de um sistema acusatório em que o criminoso também seja visto como sujeito do processo e alvo de direitos fundamentais. 
Zaffaroni (2001), ao realizar a análise do exercício do Poder Punitivo em suas origens, afirma que durante muito tempo, mesmo o Estado hoje caracterizado como democrático, tratou o criminoso atribuindo-lhe apenas uma condição de objeto perigoso e negando sua real condição de pessoa. Por sua vez, o Direito Penal cumpriu seu papel de legitimar tal discriminação. Esta maneira de agir transformava o criminoso em verdadeiro inimigo estatal, que deveria ser combatido a qualquer custo.

Acontece que esta figura construída de inimigo estatal não é em nada compatível com um Estado de Direito; posto que este último possui instituições e normas que proíbem a sinalização arbitrária dos indivíduos como inimigos estatais (ZAFFARONI, 2001). Tendo infringido as leis penais ou não, o certo é que todos, pelo simples fato de serem humanos, possuem uma dignidade mínima que deve ser respeitada e que lhes garante o direito à obediência estatal de todos os procedimentos e ressalvas legais para que haja uma apuração dos fatos e um julgamento justos; ou ao menos, o mais próximo possível da justiça concreta. Portanto, qualquer lei, doutrina ou jurisprudência que permita a restrição da liberdade sem um devido processo; violações de privacidade sem ordem judicial; tribunais de exceção ou manutenção de prisões perpétuas; configura um sistema penal paralelo ao constitucional e que remete a Estado ditatoriais e não democráticos (ZAFFARONI, 2001).

Além do mais, a adoção da visão do acusado como inimigo estatal proporciona aos sistemas autoritários e à mídia polemizadora argumentos para deslegitimar as instituições e normas, tomando estas como burocracias desnecessárias e que dificultam o combate à criminalidade. Contudo, se não for assim, se não houverem garantias legais e procedimentais, tende-se a acabar em homogeneização e arbitrariedades o que não se adequa às ideias de pluralidade e tolerância que balizam os Estados democráticos e que acabam por desaguar em ditaduras, genocídios e limpezas éticas (ZAFFARONI,2001).

Aí reside a importância gritante de se preservarem os princípios do Estado de Direito e os postulados de direitos fundamentais, pois, como afirma Zaffaroni (2001,p.153): “É justamente onde os estados de direito apresentam mais defeitos reais ou históricos que mais se precisa cuidar da intangibilidade do modelo ideal que deve orientar seu aperfeiçoamento". Diante de tais palavras, tem-se que, justamente porque, no período autoritário brasileiro se visualizou uma absurda degradação do ser humano, é que a nova ordem constitucional prega uma ideia de fraternidade social, onde não há, e nem precisa haver a eleição de um inimigo 
estatal; e onde se busca a resolução dos conflitos de forma pacífica e com base em um eixo pro homine (SILVERIO JUNIOR, 2014).

Segundo Silvério Junior (2014), o preâmbulo da Constituição Federal veda a ideia de inimigo ao estabelecer que o Estado de Direito brasileiro não se valerá de guerra para solucionar nem os conflitos externos e nem os internos. Pois, de tal postulado se compreende que no âmbito de resolução de seus conflitos internos, o desrespeito às leis do Estado será resolvido exclusivamente com base nos procedimentos previstos nestas próprias leis e sem a configuração de nenhum tipo de inimizade que possa vir a excitar condutas arbitrárias e violadoras de garantias humanas. Portanto, proteger e zelar pelos direitos do acusado no Processo Penal é condição sine qua non para se evitar o retorno às raízes ditatoriais brasileiras e manter as conquistas e avanços democráticos.

Para tanto, é preciso que a lógica do jogo processual penal opere de modo a desconstruir a ideia de inimigo, afastando a equivocada premissa de que é preciso um ato de violência estatal para punir as violências praticadas individual ou coletivamente. Neste sentido, o processo penal pode ser conduzido como um antídoto ou um catalisador para o mal da violência; pois, apesar de ser um instrumento forjado para a garantia da democracia; o desenrolar de tal procedimento é, por si só, um risco, no qual acusação e defesa geram, simultaneamente, angústias e expectativas (SILVERIO JUNIOR, 2014). Tudo dependerá, portanto, da maneira como o jogo é conduzido e do obedecimento em maior ou menor escala de suas regras.

\section{ESTABELECENDO AS REGRAS DO JOGO PENAL: O OBJETO DO PROCESSO,}

\section{A LUTA PELO DIREITO E A NECESSIDADE DE EQUILÍbRIO E CONSITUCIONALIZAÇÃO DO SISTEMA}

Entende-se, na trilha de Jaime Guasp (apud GLOECKNER, 2009), que o objeto do direito, seja Penal ou Civil, é sempre uma pretensão jurídica que se consubstancia na possibilidade de exigência de que alguém realize uma prestação positiva ou negativa. Tal conceito sugere uma relação jurídica bilateral entre partes. Entretanto, a partir da teoria processual da relação jurídica de Oskar Von Bülow (1998), sabe-se que a relação no processo, na verdade é trilateral, uma vez que juntamente com as partes existe o Estado, na posição de terceiro imparcial. Assim, a pretensão processual penal é ato que visa à obtenção de provimento estatal para a realização de determinado interesse jurídico. Apresentam-se, então, 
na seara penal, uma pretensão material, que decorre do conflito de interesse entre as partes, e uma pretensão processual, que emana das partes para o Estado, traduzindo-se por uma expectativa de mediação justa da lide, com a consequente satisfação da pretensão material (GLOECKNER,2009).

Neste contexto, vislumbra-se que a pretensão punitiva poderia enquadrar-se como pretensão material, representando o poder Estatal de submeter o autor de um delito às sanções penais correspondentes, e efetivando, assim, o ius puniendi. Entretanto, em respeito aos direitos e às garantias fundamentais, a mencionada pretensão punitiva não poderia ser alcançada sem a realização prévia de um devido processo penal, posto que o Estado não pode autoaplicar as normas de Direito Penal material. Portanto, no processo será desenvolvida outra pretensão, distinta da pretensão material, apesar de fundamentada nesta. Assim, o objeto do Processo Penal será uma pretensão acusatória; ou melhor, segundo o raciocínio de Badaró (2002), o objeto processual penal não será a imputação, mas sim aquilo que foi imputado, ou seja, o fato criminoso cuja autoria se atribuiu a alguém.

O direito que compete ao Ministério Público - ou ao ofendido- será, então, um direito ao processo; e não um direito à punição - que compete ao Estado. Entretanto, como o processo deve sempre respeitar e realizar as garantias constitucionais das partes envolvidas, também há de se considerar como função processual o suporte ao direito de resistência do acusado consubstanciado nos institutos jurídicos de defesa. Portanto, o escopo processual penal será atingido com a realização de qualquer uma das pretensões mencionadas: seja pela pretensão acusatória, com a declaração de culpa do imputado ou, com a pretensão de resistência, através da opção pela liberdade do mesmo (LOPES JUNIOR, 2002).

Portanto, utilizando-se, por sua vez, da teoria processual das situações jurídicas, cunhada por James Goldschmidit (2002), observa-se que as situações jurídicas, no desenrolar do Processo Penal, consubstanciam-se em oportunidades de argumentação e provas que desaguam em perspectivas de condenação ou de absolvição. Goldschmidit (2002) põe em cheque a falsa noção de processo seguro trazida por Bülow e ressalta o caráter dinâmico do mesmo; demonstrando, ainda, que a certeza própria do direito material desaparece na fase processual e dá lugar á incerteza que lhe é característica.

Se o objeto do Processo Penal é uma pretensão jurídica acusatória, este não pode ser figurado como uma simples relação jurídica estática e imutável entre partes com direitos e deveres preestabelecidos, posto que deve ser entendido como uma teia dinâmica de situações 
mutáveis, cujo resultado poderá ser alterado de acordo com o sucesso ou a falta de êxito das partes de livrarem-se do ônus processual. No Processo Penal existe a possibilidade de uma sentença condenatória, concretizada mediante a maneira pela qual as partes utilizam os meios probatórios disponíveis, influenciando a formação da convicção do magistrado num sentido ou em outro. Assim, a situação jurídica é variável de modo que o Processo Penal propiciará uma sentença condenatória, se a acusação se desincumbir de seus ônus processual ou uma sentença de caráter absolutório, caso a defesa obtenha mais sucesso em desvencilhar-se de seus deveres probatórios (GLOECKNER,2009).

\subsection{O Processo Penal na sociedade de risco: a luta pelo direito}

Não se pode ignorar, contudo, que a luta pela plena concretização de direitos não se restringe apenas às partes envolvidas no processo, posto que, no desenrolar processual, o Estado assume, por meio do órgão ministerial e do Poder Judiciário o papel mais importante, uma vez que pune legitimamente os delitos prejudiciais aos interesses individuais e, sobretudo, sociais (VIN LHERING, 2011). A defesa do Direito é um dever com a própria comunidade. Entretanto, numa sociedade cercada por diversas condutas e situações de risco, a função principal do Direito passa a ser controlar os riscos, já que não possui meios para se livrar deles (PRIEST,1999).

O Direito Penal do risco se utiliza, portanto, de um Processo Penal também orientado pelos riscos. Na tentativa de controlar os riscos sociais, o processo vai ser utilizado como o meio de punir aqueles que desviam da norma padrão e criam ou fomentam os mencionados riscos. O desviante será tratado como inimigo estatal, causador da desordem e alvo necessário de reprimendas; o processo, por si só, acarretará ao acusado sofrimentos e, para que este sofrimento seja minorado, há de se enxergar o instrumento processual como meio para a redução de danos. Ou seja, para um processamento devido, há que se blindar o réu com garantias impeditivas das arbitrariedades do Poder estatal (GLOECKNER, 2009).

Não obstante a responsabilidade estatal, mas recapitulando a lição de Goldschmidit, há de se ter em mente que processar alguém significa reconhecer uma situação jurídica que torna alguém imputado por um fato criminoso, o qual, ao fim e a cabo, com base na força das teses levantadas num ou noutro sentido, será julgado como procedente ou não (GLOECKNER, 2009). Por isso é que Rudolf Von Lhering (2011,p.93) já dizia que não existe Direito sem luta, pois, "só deve merecer a liberdade e a vida quem para conservá-las luta constantemente". 
A luta pelo Direito é, portanto, um dever do interessado consigo mesmo, devendo utilizar-se dos meios disponíveis para provar a legitimidade de seu direito e evitar que seja desconsiderado.

Ninguém compreende tão bem a importância da liberdade quanto aquele que se encontra ameaçado de perdê-la, devendo ser responsável por defender com igual intensidade seu interesse em juízo (VON LHERING, 2011). Sendo assim, a analogia do processo a guerra tende a evidenciar que no processo - assim como nas guerras- vence quem melhor souber aproveitar suas chances. Como em qualquer guerra, o processo penal está sempre eivado de incertezas que se justificam pela existência de iguais probabilidades no sentido de uma decisão judicial justa ou injusta, já que, o direito de punir só será tido como existente ou não no fim do processo com o desfecho da cognição judicial e o término dos esforços das partes no sentido de influenciá-la (LOPE JUNIOR, 2002).

A incerteza processual decorre de dois fatores principais: primeiramente, porque o Processo Penal demanda a reconstrução histórica de um fato passado, que nem sempre será recontado de maneira fidedigna; segundo, porque o trâmite processual carrega em si riscos endógenos que derivam das decisões tomadas pelo magistrado e pelas próprias partes na prática de seus atos processuais. A decisão do juiz decorre da apreciação das duas reconstruções históricas elaboradas pelas partes para a construção de uma terceira história, formada com base nas convicções do próprio julgador, geradas pelos liames probatórios apresentados ou não pelos interessados (GLOECKNER,2009). Desse modo, tem-se que o julgador não é livre para dar razão a quem mais o sensibilizar ou satisfizer suas aspirações e valores pessoais, posto que, não escapará do contexto histórico, construído a partir da apreciação das provas efetivamente trazidas aos autos. Sendo assim, pode-se afirmar que a habilidade técnica das partes é crucial para fazer valer o direito postulado (LOPES JUNIOR, 2014).

Entretanto, faz-se mister salientar que, no Processo Penal, a distribuição do ônus probatório não é igual, posto que o acusado está constitucionalmente respaldado pelo princípio da presunção de inocência. Sendo assim, na ação penal pública, cabe ao MP demonstrar a culpabilidade do acusado. Se o referido órgão ministerial não se "desincumbir" de sua carga probatória, a alternativa ao magistrado será a de conceder a absolvição. Não compete ao acusado provar sua inocência, mas sim, ao Estado, provar sua culpa. Portanto, se o Estado, na figura do parquet, reconhecer que não possui arcabouço probatório suficiente 
para sustentar um pedido de condenação, não há que se vislumbrar qualquer possibilidade de que o julgador decida em tal sentido. Como reiteradamente mencionado, o objeto processual penal não é a pena, pois não se baseia em uma pretensão punitiva; o objeto em questão é uma pretensão acusatória, que gira, por óbvio, em torno da acusação; e que, se desenvolvida, possibilita ao juiz o exercício do ius puniendi, mas, se não efetivada, impede a punição (LOPES JUNIOR, 2014).

\subsection{O necessário equilíbrio entre poder acusatório, direito de defesa e poder punitivo}

Diante do exposto, observa-se, então que, para um funcionamento adequado e democrático do Direito material e processual Penal, é fundamental a existência de equilíbrio e balanço entre o poder acusatório exercido pela vítima ou pelo órgão ministerial; a plenitude do direito de defesa do acusado e o poder punitivo a ser exercido cabalmente pelo Estado. Tal necessidade se manifesta como imprescindível uma vez que, para o bom funcionamento de qualquer sistema, o equilíbrio entre seus elementos é fundamental (LEAL, 2017). Destarte, o sistema criminal só estará apto a realizar a missão que lhe foi designada se o acusado tiver condições mínimas de se defender diante do gigante poder punitivo do leviatã estatal.

Mas qual seria a missão do Direito Penal?! Pode-se dizer que, a partir do momento em que passou a vigorar na sociedade o famigerado contrato social, o Direito Penal assumiu o papel de legitimar e estabilizar as condições de tal contrato (BECHARA, 2008). Uma vez que os cidadãos renunciam parte de suas liberdades individuais em prol da ordem estatal, os limites desta "contratação", por envolverem direitos muito fundamentais, devem ser muito bem delineados e fiscalizados. O Direito Penal é, neste contexto, guardião, fiscal e, muitas vezes, carrasco. Paradoxalmente, ao mesmo tempo em que o Penal é o meio legítimo de perpetração da punição e da violência; este desempenha, também, a função de garantir as liberdades individuais. Como menciona Silva Sánchez (1992): "É Direito que se manifesta em conflito de finalidades: preventivo por um lado e garantista pelo outro".

Assim, para que se possa falar em uma intervenção penal eficaz e legítima, há de se realizar a ponderação entre os benefícios e os custos acarretados pela aplicação da pena, bem como a avaliação de quem e como deverá suportar esse custo; a fim de que se alcance um equilíbrio entre tais parâmetros. Tal análise, entretanto, não pode apresentar um objetivo simplesmente econômico, pois também precisa ser efetiva no sentido de dar uma resposta estatal e social ao infrator. O objetivo, então, é trabalhar com um sistema que garanta a 
integridade social em face de possíveis agressões; mas sem agredir excessivamente os direitos individuais. Para isso, o respeito aos princípios e garantias constitucionais deve ser sempre o norte da atuação criminal (POZUELO PEREZ, 2003).

Pode-se afirmar, então, que a tarefa daqueles que operam as regras do jogo penal consiste num exercício de superar as aparentes contradições entre norma e realidade e saber lidar com a emergência e os apelos por segurança pública; tendo sempre em mente que a violência estatal extremada apenas abrirá as portas para uma cada vez maior violência social. O trabalho penal corresponde, então, a tentativas de solucionar os conflitos concretos de maneira harmoniosa com o que foi estabelecido pelo ordenamento. Ressaltando-se, como o faz Ana Elisa Bechara (2011) que: “Tal sistema, é bem verdade, não pode ser considerado como definitivo ou fechado, mas sim como suscetível a modificações a novas harmonizações quando essas se mostrarem necessárias, no enfrentamento de novos problemas”. Ou seja, apesar da inegável necessidade de adequação às situações, problemáticas e impasses impostos pela realidade; há sim de se postular por uma obediência aos preceitos do Estado Democrático de Direito e pelas normas de Direito Criminal que resguardam os direitos fundamentais e humanos.

Óbvio que, por lidar com bens jurídicos de extrema sensibilidade e importância, o âmbito criminal não pode se sujeitar a uma abertura demasiada; mas uma moderada abertura da racionalidade penal, mas do que do próprio sistema, é fulcral para fugir do reinado da "lei pela lei" e adotar a necessária crítica racional que a práxis penal precisa realizar para solucionar, de maneira mais coerente e menos violenta os casos concretos. É desta forma que o penal poderá deixar de ser visto socialmente apenas como poder simbólico e passará a ser visto como poder real (BECHARA, 2011).

\subsection{Os limites da normatividade e a dificuldade de constitucionalização do ordenamento penal brasileiro}

O exercício de uma racionalidade penal que busque equilíbrio entre norma e realidade e entre emergência de solução dos problemas reais com a observância dos preceitos constitucionais se mostra, contudo, de difícil aplicação no contexto atual da realidade brasileira que se mostra, ainda, extremamente normativa e fechada sobre si mesma. O Direito Penal da modernidade sofre, então, com um lento e dificultoso processo de abertura. 
A concepção clássica de Direito Penal se estabeleceu na Europa do século XVIII, onde a justiça divina passou a ser substituída por uma justiça humana pautada nas leis. Desta forma, o Direito Penal era visto como um conjunto específico de normas que pouca relação tinha com as demais áreas do Direito. Contudo, o pensamento penal clássico passou a ser questionado pelas diversas escolas de pensamento penal que surgiram, o que fez com que as práticas e o campo de observação penal se modificassem, de modo que a Ciência do Direito Penal se alargou em razão da perda da especificidade das categorias penais, devido ao crescimento da complexidade dos fenômenos criminais; e do esboço de novas categorias oriundas da grande propagação mundial dos Direitos Humanos (DELMAS-MARTY, 2004).

Com relação ao primeiro ponto, passa-se a reconhecer um Direito Penal que não se limita ao estudo da matéria criminal, mas que se transformou em uma ciência mais do que multidisciplinar, mas, necessariamente transdisciplinar, pois precisa agregar elementos de outros ramos do Direito e de Ciências externas para formular seus conceitos e institutos. Vislumbra-se um penalismo que vem se socorrendo de técnicas de mediação, de repressões administrativas e de institutos civilistas de indenização das vítimas; na tentativa de se desafogar.

O Direito Penal foi forjado para ser a ultima ratio e, portanto, não consegue, sozinho, atender à crescente demanda por penalização e criminalização de matérias e comportamentos que, nem sempre deveriam ser direcionados para esta seara de juridicialização. A transdisciplinariedade possibilita a produção de uma teoria única a partir de campos ou ramos do conhecimento autônomos (GUSTIN,2006) e, essas novas estratégias estatais e sociais que o Direito Penal tem buscado para responder às infrações ou às condutas de desvio das norma (DELMAS-MARTY, 2004) tem gerado um campo novo, amplo e puramente interdisciplinar de estudo da criminalidade, que tem sido denominado pela melhor doutrina de Política Criminal.

Contudo, como anteriormente mencionado, a dificuldade de implementação da Política Criminal no cenário brasileiro tem se dado em razão da flexibilização excessiva de regras e valores em um ambiente caracterizado por um forte posicionamento político no sentido da prevenção. Justamente por isso é que, diariamente, princípios fundamentais e regras de Direito Penal são deixados de lado em prol do atendimento social prevencionista e repressista (D ÁVILA, 2008). Os conceitos e os institutos mais tradicionais de Direito Penal e, até mesmo aqueles oriundos da norma constitucional, como a presunção de inocência e o in dubio 
pro reo são frequentemente "flexibilizados" quando começam a representar um empecilho para a consecução dos fins políticos estatais.

Daí, estamos aptos a localizar o problema no cerne do sistema de Direito Penal: o princípio unificador que deveria zelar pela boa e correta aplicação de todos os demais elementos, que é a Constituição Federal, ainda esboça, em âmbito político criminal uma força normativa muito inexpressiva, que não consegue, ou não se esforça para conseguir, competir com os arbítrios políticos estatais. Com a força normativa do princípio unificador debilitada, as demais engrenagens do sistema não funcionam devidamente e, então, temos a famigerada crise: crise do Direito e do Processo Penal, crise dos poderes estatais, crise da Democracia. Silva Sanchez (2001) denomina o momento atual como uma terceira crise da Ciência Penal que se caracteriza por uma supervalorização das respostas punitivas. Tal cenário crítico é causado, entre outros fatores, pela falta de vinculação dos titulares dos poderes públicos às regras jurídicas e aos valores constitucionais. Pois, como ensina Ferrajoli (2011A), a ilegalidade pública se manifesta também em forma de crise constitucional, com a degradação dos valores e regras constitucionais e dos limites que estes impõem ao exercício dos poderes públicos.

O discurso da Política Criminal está tão em voga que a dimensão político-criminal acaba sempre sendo priorizada quando da aplicação das normas penais, relegando para um outro momento ou, simplesmente, deixando passar, o critério mais importante para filtrar a realização de qualquer prática penal, qual seja, a adequação jurídico-constitucional da mesma (D AVILA, 2008). Ou seja, a realização adequada da abertura do Direito Penal deve obedecer a uma ordem; e esta ordem deve se dar de modo que, primeiro há de se compatibilizar as decisões penais com os comandos constitucionais, e, só em um segundo momento é que se deve avaliar sua adequação e pertinência em termos de política criminal. Portanto, qualquer interesse estatal, por melhor que seja, possuindo cunho preventivo, ressocializador ou punitivo; só poderá ser efetivado se estiver dentro dos limites estabelecidos pelas normas penais e, sobretudo, pelos ditames constitucionais.

Temos, portanto, que a Política Criminal deve sim ser utilizada como elemento de abertura do Direito Penal, como alternativa aos processos de criminalização e penalização em massa e como auxiliar do direito material e processual no que lhe for útil e compatível. Mas não é possível sobrepor os anseios de cunho político ao atendimento das normas constitucionais; porque sim, a Ciência Penal não apenas restringe direitos, mas também é 
responsável por concretizar muitos deles; devendo garantir liberdade e segurança mais amplas e eficazes do que aquelas que poderiam ser atribuídas aos titulares sem sua intervenção (YACOBUCCI, 2005).

\section{CONCLUSÃO}

Diante de todo o exposto, pode-se concluir, então e, primeiramente, que não há como realizar um estudo adequado do Direito Penal sem ter em mente que o exercício do mesmo implica, necessariamente, em uma expressão do Poder Estatal. O Poder é ente despersonalizado que necessita de quem o titularize e, no contexto do contrato social firmado entre a sociedade e o Estado, este último é que será responsável por atribuir concretude ao Poder Social e por fazer valer as normas jurídicas, aplicando, quando necessário as sanções cabíveis. E, é através da realização deste raciocínio que se fará possível compreender, de maneira mais ampla, o exercício do poderio criminal.

Ocorre que o exercício do Poder Punitivo estatal é, paradoxalmente, um mecanismo de luta contra a violência mas que também se manifesta através de condutas violentas; as quais só são admitidas e legitimadas através das normas de Direito Penal material e dos mecanismos de Processo Penal. Justamente por isso, se faz mister trabalhar na jurisprudência e na doutrina a necessidade de observância dos procedimentos e garantias penais; assim como a visualização do Processo Penal como um instrumento acusatório e democrático, e não inquisitório ou autoritário. Caso contrário, o Direito e o Processo Penal sempre irão servir como instrumentos de opressão e não atingirão a sua principal finalidade, que é a de garantir e preservar as liberdades individuais.

Sabe-se que, na maioria das vezes, a pressão e o desespero popular por segurança pública, em face ao aumento alarmante dos números e da complexidade da criminalidade; fazem com que a sociedade pugne por um Direito Penal punitivo e repressivo a qualquer custo e, tal fenômeno gera, ciclicamente, uma crise de legitimidade das normas criminais. Contudo, ainda assim, há de se ter em mente que o principal objetivo das mencionadas normas é concretizar e garantir direitos fundamentais; e não sacrificar direitos em demasiado e em prol apenas da tentativa de conferir força à segurança pública. $\mathrm{O}$ uso do Penal não pode reproduzir em âmbito estatal a violência que já foi realizada na esfera individual.

O Direito Criminal deve ser visto sempre, como ensinou o Mestre Ferrajoli, como a lei do mais fraco em detrimento da lei do mais forte. Ou seja, deve-se buscar ao máximo a 
garantia dos direitos de defesa do acusado em face do grande poderio de repressão estatal. É justamente a observância aos direitos fundamentais do réu e de todos os envolvidos no processo penal que vai garantir que o Direito Penal possa combater a violência sem introduzir na sociedade mais violência.

Destarte, tomar o respeito aos direitos individuais e à dignidade da pessoa humana, então, é o que vai garantir que se ponha fim à visão do acusado como inimigo estatal; que se ponha termo à suposta inimizade existente o ente estatal e os causadores de desordem social. Portanto, o objetivo estatal, quando do exercício de seu Poder Penal, não deve ser de medir forças com o suposto inimigo estatal, mas sim reestabelecer a ordem que foi abalada por este.

Assim, para um bom e correto funcionamento do sistema penal, é necessário, primeiramente, visualizar que o objeto do processo penal não é uma pretensão de punição a todo e qualquer custo, mas sim uma pretensão de acusação; ou seja, uma pretensão de que aquele que desviou das normas estatais seja julgado e, dentro dos moldes impostos pela legislação criminal, punido ou absolvido; e não que o Estado tenha algum direito incontestável de exercer o seu jus puniendi em toda e qualquer situação.

A sociedade se caracteriza pelo risco e, muitas vezes, não podendo combatê-lo, o Estado, através do exercício criminal, deve tentar diminuí-lo ao máximo possível; mas sempre obedecendo às regras do procedimento penal e à axiologia constitucional. Para que haja efetividade na aplicação do Direito Penal deve sempre haver, então, o equilíbrio entre o poder acusatório, exercido pelo Estado; o direito de defesa do indivíduo; e o poder punitivo, também exercido pelo Estado. Deve-se levar sempre em consideração, então que, na grande maioria dos procedimentos criminais, o Estado se faz presente duas vezes, enquanto que o acusado, apresenta-se individualmente.

Há, portanto, que se obedecer aos preceitos constitucionais; obedecer sim à normatividade legal penal; mas de maneira valorativa. Sempre entendendo que o Direito é dinâmico e que as situações são relativas. Abrindo, na medida do possível, o espaço criminal para o exercício de uma razão crítica sobre o caso concreto. Constitucionalizar o ordenamento penal brasileiro tem se mostrado tarefa árdua, em razão, sobretudo, do pensamento social extremamente prevencionista e repressista; mas, é justamente na norma fundamental constitucional e nos preceitos de Direito Penal, através de uma aplicação crítica, que se encontrarão as respostas para um Direito Criminal mais efetivo e menos opressor da figura do réu. 


\section{REFERÊNCIAS}

ABADE, Denise Neves. Garantias do Processo Penal acusatório: O novo papel do Ministério Público no Processo Penal de partes. São Paulo: Renovar, 2005.

ADORNO, Sergio. O monopólio estatal da violência na sociedade brasileira contemporânea. In: O que ler na Ciência Social Brasileira 1970-2002. Volume IV. Org MICELI, Sergio. [S.1] : Editora ANPOCS, 2002.

BADARÓ, Gustavo Henrique R.I. Correlação entre acusação e sentença. 3 ed. São Paulo: Revista dos tribunais, 2013.

BECHARA, Ana Elisa Liberatori Silva. Discursos de emergência e política criminal: o futuro do Direito Penal brasileiro. Revista da Faculdade de Direito da Universidade de São Paulo. v.103. 2008.

$\begin{array}{llcccccc}\text { BÜLOW, Oskar } & \begin{array}{c}\text { Von. } \\ \text { presupuestos }\end{array} & \text { procesales. } & \begin{array}{c}\text { teoria de } \\ \text { Traducción }\end{array} & \text { las } & \text { excepciones } & \text { procesales } & \text { yiguel los } \\ \text { Angel } & \text { Rosas }\end{array}$ Lichtschein. Buenos Aires: Ediciones Juridicas Europa-America, 1964.

D’AVILA, Fabio Roberto. O Direito e a legislação penal brasileiros no séc XXI: entre a normatividade e a política criminal. In: GAUER, Ruth Maria Chitto (org). Criminologia e sistemas jurídico-penais contemporâneos. Porto Alegre: EdipucRS, 2008

DE GIORGI, Raffaele. Direito, democracia e risco: vínculos com o futuro. Porto Alegre: Sergio Antonio Fabris editor, 1998.

DELMAS-MARTY. Os grandes Sistemas de Política Criminal. Trad. Denise Radanovic Vieira. Barueri,SP: Manole,2004.

FACHIN, Luiz Edson. Virada de Copérnico: um convite à reflexão sobre o Direito Civil brasileiro contemporâneo. In: FACHIN, Luiz Edson (coord.). Repensando os fundamentos do Direito Civil Brasileiro contemporâneo. Rio de Janeiro: Renovar, 2000.

FERRAJOLI, Luigi. Derechos e y garantias: la ley del mas débil. S.I. Editorial Trotta. 2011. Por uma Teoria dos direitos e dos bens fundamentais. Tradução Alexandre Salim et al. Porto Alegre: Editora Livraria do advogado, 2011.

FOUCAULT, Michel. A verdade e as formas jurídicas. 3 ed. Rio de Janeiro: Nau Editora, 2002.

Cultura Social, 2009.

Do governo dos vivos. Tradução Nildo Avelino. São Paulo: Centro de

Em defesa da sociedade. Tradução Maria Ermantina Galvão. São Paulo: Martin Fontes, 2005. 
35 ed. Petrópolis: Vozes, 2008.

. Vigiar e punir: nascimento da prisão. Tradução de Raquel Ramalhete.

GIACOIA JUNIOR, Oswaldo. Direito, Estado e Sujeito de Direito. Revista Reflexões, a.7, n.12. Fortaleza-CE. Jan-jun, 2018.

GIACOMOLLI, Nereu Jose. O devido processo penal. São Paulo: Atlas,2014.

GLOECKNER, Ricardo Jacobsen. Risco e Processo Penal: Uma análise a partir dos direitos fundamentais do acusado. Salvador: JusPODIVM, 2009.

GOLDSCHMIDIT, James. Princípios gerais do Processo Penal. S.l: Editora Líder, 2002.

GUSTIN, Miracy Barbosa de Sousa; DIAS, Maria Tereza Fonseca. (re) pensando a pesquisa jurídica: teoria e prática. 2 ed. Belo Horizonte: Delrey, 2006.

LEAL, Pastora. Sistemas de Direito. Belém, 2017. Aula ministrada no Mestrado em Direitos Fundamentais da Universidade da Amazônia - UNAMA, em 21 fev,2017.

LOPES JUNIOR, Aury. Direito processual penal. 11 ed. São Paulo: Saraiva, 2014. (Re)Discutindo o objeto do processo penal com Jaime Guasp e James Goldschmidit. Revista Brasileira de Ciências criminais, São Paulo, SP, v.10, n.39, p.103124, julho/set. 2002.

LOCKE, John. Dois tratados sobre o governo. Tradução Julio Fischer. São Paulo: Martins Fontes, 1998.

MARTÍNEZ, Gregorio Peces-Barba. Textos básicos sobre derechos humanos. Madrid: Universidad complutense, 1973.

MATTOS, Sérgio Luís Wetzel de. Devido processo legal e proteção de direitos. Porto Alegre: Livraria do advogado, 2009.

MORAES, Guilherme Braga Penã de. Dos direitos fundamentais: contribuição para uma teoria. São Paulo: Editora LTR.1997.

PASOLD, Cesar Luiz. A função social do Estado contemporâneo. Florianópolis: Editora do Autor, 1984.

PEREZ LUNO, Antonio Enrique. Delimitacion conceptual de los derechos humanos. In: CASTRO, José Cascajo et al. Los derechos humanos, significacion, estatuto jurídico y sistema. Publicaciones de la Universidad de Sevilla. 1979.

POZUELO PÉREZ, Laura. De nuevo sobre la denominada 'expasión' del derecho penal: una relectura de los planteamientos críticos. In: LYNETT, Eduardo Montealegre (Coord.). El funcionalismo en derecho penal. Colombia: Universidad Externado de Colômbia, 2003, t. II. 
PRIEST, George L. The new legal structure of risk control. In. Daedalus, vol.119, n.04. Chicago, 1990.

SÁNCHEZ, Jesús María Silva. Aproximación al derecho penal contemporáneo. Barcelona: Bosch, 1992.

La expansion del derecho penal: aspectos de la politica criminal em las sociedades postindustriales. 2 ed. Madrir: Civitas, 2001.

SARMENTO, Daniel. Direitos fundamentais e relações privadas. Rio de Janeiro: Lumens Juris, 2004.

SILVERIO JUNIOR, João Porto. Processo Penal fraterno: o dever de fundamentar o provimento acusatório pelo Ministério Público no sistema processual brasileiro. Curitiba: Juruá, 2014.

STRECK, Lenio Luiz; MORAIS, Jose Luiz Bolzan. Ciência Política e Teoria do Estado. 8 ed. Porto Alegre: Livraria do advogado Editora, 2014.

VEIGA-NETO, Alfredo. Foucault e a educação. Belo Horizonte: Autêntica, 2003.

VON LHERING, Rudolf. A luta pelo direito. 24 ed. Rio de janeiro: Forense, 2011.

YACOBUCCI, Guillermo Jorge. Limites racionales al derecho penal. In: SOUZA, Bernardo de Azevedo e; SOTO, Rafael Eduardo. Ciências criminais em debate. Rio de Janeiro: Lumen Juris, 2015.

ZAFFARONI, Eugenio Raul. O inimigo no Direito Penal. Tradução Sergio Lamarão. [s.1]: Revan, 2001.

ZAGREBELSKI, Gustavo. El derecho dúctil. Traducion de Marina Gascon. [s.1]: Editorial Trotta, 1995. 